\title{
ANALISIS DAMPAK PENGANGGURAN TERHADAP KEMISKINAN DI DKI JAKARTA
}

\author{
Darma Rika Swaramarinda \\ Fakultas Ekonomi Universitas Negeri Jakarta
}

\begin{abstract}
This article was aimed at describing connections between unemployment to poverty in DKI Jakarta. In this article, the analysis use descriptive-qualitative. This analysis described in descriptive about unemployment and poverty in DKI Jakarta. Unemployment that occured in DKI Jakarta making poverty is increasing and that seen everywhere. The increase of unemployment in development countries emerging due to the slow growth of employment than the the rapid growth of labor force. Policies need to be created by the local government that can increase the demand of unskilled labor in order to facilitate poor peoples sell their labor and reduce the number of unemployment.
\end{abstract}

\section{PENDAHULUAN}

Di negara Indonesia yang merupakan salah satu negara berkembang saat ini tetap terlihat kemiskinan di mana-mana, berbeda dengan data yang menunjukkan bahwa pertumbuhan ekonomi kita tetap meningkat walaupun melambat. Perhatian utama terfokus pada dilema kompleks antara pertumbuhan versus distribusi pendapatan. Keduanya sama-sama penting namun sulit diwujudkan secara bersamaan. Pengutamaan yang satu akan menuntut dikorbankannya yang lain. Pembangunan mensyaratkan Gross Domestic Product (GDP) yang lebih tinggi, dan untuk itu tingkat pertumbuhan yang lebih tinggi merupakan pilihan yang harus diambil.

Pemerintahan
diharapkan memberikan dampak
yang baik untuk pertumbuhan
ekonomi Negara Indonesia
khususnya DKI Jakarta sebagai
pusat ibu kota. Kebijakan-kebijakan
yang diambil untuk mengurangi
kemiskinan yang ada oleh
Pemerintah Provinsi DKI Jakarta
juga masih ada yang pro-kontra di
internal pemerintahan sendiri, yaitu
Oleh Kepala Daerah dengan wakil
rakyat yang ada di Provinsi.
Namun yang menjadi
masalah bukan hanya soal
bagaimana caranya memacu
pertumbuhan, tetapi juga siapa yang
pantas melakukan, kalangan elit
kaya yang minoritas, ataukah
mayoritas rakyat yang miskin.
Seandainya yang diserahi
wewenang itu adalah kelas kaya,


maka mereka akan mampu memacu pertumbuhan dengan baik, akan tetapi kemungkinan kondisi ketimpangan pendapatan dan kemiskinan absolut tidak dapat segera teratasi. Tetapi jika yang dipilih adalah mayoritas rakyat miskin, segenap hasilnya harus dibagi secara lebih merata, dan hal ini yang menyebabkan pertumbuhan ekonomi tidak terlalu tinggi.

Dewasa ini diakui secara luas bahwa pertumbuhan GDP, yang diukur secara konvensional, tidak memuaskan sebagai tujuan dan keberhasilan pokok dari pembangunan. Diantara banyak alasan mengapa ini diterima secara umum adalah sebagai berikut. Pertama, banyak negara berkembang yang telah mengalami laju pertumbuhan GDP yang pesat, secara berbarengan juga mengalami pengangguran yang meningkat. Laju pertumbuhan lapangan kerja ternyata jauh lebih lamban dari laju pertumbuhan GDP, dan pertumbuhan pesat dalam GDP sering pula disertai oleh kepincangan dalam pembagian pendapatan yang makin besar (kemiskinan relatif) dan, dalam beberapa hal, kemiskinan absolut yang makin besar daripada beberapa golongan.

$$
\text { Gejala bertambahnya }
$$
pengangguran dan pembagian pendapatan yang makin pincang saling berkaitan, artinya kedua tingkat pendapatan (relatif atau absolut) yang lebih rendah terutama terdapat di antara mereka yang tidak berhasil memperoleh pekerjaan, sedangkan hasil-hasil dari pertumbuhan GDP terpusat pada mereka yang mempunyai pekerjaan. Pengangguran terbuka bukan merupakan ukuran yang memuaskan bagi kemiskinan, karena para penganggur terbuka pada umumnya lebih baik keadaannya, sedangkan mereka yang benar-benar miskin tidak mungkin menganggur. Tetapi kemiskinan dapat dijadikan ukuran memadai bagi sebagian dari masalah kesempatan kerja, karena kelebihan persediaan tenaga kerja yang mencari pekerjaan tercermin pada penghasilan rendah yang disebabkan tidak adanya lapangan kerja sama sekali (pengangguran terbuka), kekurangan pekerjaan (jam kerja yang sedikit), atau pekerjaan dengan produktivitas yang sangat rendah (sumbersumber daya pelengkap yang tidak mencukupi atau produktivitas rendah yang disebabkan oleh tingkat hidup yang rendah)

$$
\text { Seseorang }
$$
dianggap pengangguran jika dia tidak bekerja sama sekali, atau sedang mencari pekerjaan dan siap bekerja tetapi tidak memperoleh pekerjaan. Sedangkan tingkat pengangguran adalah perbandingan jumlah penganggur dengan jumlah angkatan kerja yang dinyatakan dalam persen.

$$
\text { Peningkatan pengangguran }
$$

di negara-negara yang sedang berkembang disebabkan oleh lambatnya pertumbuhan kesempatan kerja daripada pertumbuhan yang cepat dari angkatan kerja. 
Badan Pusat Statistik (2000) faktor utama penyebab kemiskinan terutama karena faktor alamiah. Seseorang menjadi miskin karena mereka dilahirkan dari keluarga miskin. Kemiskinan menyebabkan mereka tidak hanya kesulitan dalam memenuhi kebutuhan dasar tetapi juga tidak mampu mengembangkan status sosialnya. Dengan kata lain, kemiskinan merupakan mata rantai yang bila tidak diputus akan menyebabkan kemiskinan tersebut selalu ada.

\section{Kemiskinan}

Kemiskinan merupakan permasalahan yang selalu timbul di negara berkembang dan negara sedang berkembang, termasuk Indonesia. Walaupun sudah banyak program-program yang ditujukan dalam upaya penghapusan kemiskinan, namun masalah ini tak kunjung selesai juga. Sulitnya penyelesaian masalah ini disebabkan karena permasalahan yang melibatkan penduduk miskin ternyata sangat kompleks. Mencari pengertian kemiskinan bukanlah hal yang mudah. Kemiskinan sebagai suatu gejala sosial akan berbeda dengan kemiskinan sebagai gejala ekonomi. Kemiskinan sosial (cultural) lebih banyak berkaitan dengan sikap hidup penduduk miskin yang tidak mempunyai keinginan untuk maju dan berusaha memperbaiki taraf kehidupan. Sedang kemiskinan ekonomi merupakan suatu gejala yang terjadi di sekitar lingkungan penduduk miskin dan biasanya dikaitkan dengan masalah pendapatan.

Konsep kemiskinan pada dasarnya berkaitan dengan tingkat pendapatan dan kebutuhan. Kebutuhan hanya dibatasi pada kebutuhan pokok atau kebutuhan dasar minimum yang memungkinkan seseorang dapat hidup secara layak. Jika tingkat pendapatan tidak dapat memenuhi kebutuhan minimum, maka orang atau rumah tangga tersebut dikatakan miskin. Dengan kata lain, kemiskinan dapat diukur dengan membandingkan tingkat pendapatan orang atau rumah tangga dengan tingkat pendapatan yang diperlukan untuk memenuhi kebutuhan minimum. Dengan demikian, tingkat pendapatan minimum merupakan batas antara keadaan miskin dengan tidak miskin atau sering disebut dengan garis kemiskinan. Konsep ini dikenal sebagai kemiskinan mutlak (absolut).

Sebaliknya, walaupun tingkat pendapatan sudah mencapai tingkat kebutuhan dasar minimum, tetapi masih kecil dibandingkan dengan tingkat pendapatan masyarakat sekitarnya, maka orang atau rumah tangga tersebut masih berada dalam keadaan miskin. Konsep ini dikenal sebagai kemiskinan relative. Kemiskinan relatif berkaitan dengan masalah pembangunan yang bersifat struktural, yaitu kebijaksanaan yang belum seimbang sehingga menyebabkan ketimpangan distribusi pendapatan.

$$
\text { Masalah distribusi }
$$
pendapatan atau kemiskinan relatif berkaitan erat dengan masalah 
kemiskinan absolut karena kemiskinan absolut merupakan akibat dari ketimpangan distribusi pendapatan. Jika kesenjangan pendapatan tinggi maka jumlah penduduk miskin pun akan tinggi. Kemiskinan relatif akan selalu timbul selama masih ada ketimpangan distribusi pendapatan.

Kemiskinan absolut diartikan sebagai suatu keadaan dimana tingkat pendapatan absolut dari suatu masyarakat tidak mencukupi untuk memenuhi kebutuhan pokoknya seperti: pangan, sandang, pemukiman, kesehatan, dan pendidikan. Besarnya masalah kemiskinan absolut tercermin dari jumlah penduduk yang tingkat pendapatan atau konsumsinya berada di bawah tingkat minimum yang telah ditetapkan. Bank Dunia dalam World Development Report (1990) mendefinisikan keadaan miskin sebagai berikut "Poverty is concern with absolute standard of living of a part of society -the poorin equality refers to relative living standard across the whole society".

Tahap penting dalam usaha pengukuran skala kemiskinan adalah menentukan ukuran garis kemiskinan yang secara umum dapat diterapkan di seluruh negara. Dalam usaha menentukan kemiskinan absolut diperlukan pola taraf konsumsi minimum untuk melangsungkan kehidupan. Hal ini menjadi masalah, sebab ukuran melangsungkan kehidupan tidak dapat didefinisikan secara jelas. Dalam ukuran yang lebih sempit kita memerlukan data harapan hidup yang berlaku di dalam lingkungan tertentu. Pada saat ini ukuran harapan hidup (life expectancy) di negara-negara berkembang tergolong sangat rendah dan tidak menyediakan dasar untuk menghitung kebutuhan minimum manusia. Peningkatan tingkat harapan hidup akan menyebabkan kebutuhan untuk konsumsi akan meningkat. Dengan kata lain tingkat konsumsi riil seperti makanan, lingkungan hidup yang sehat dan kebutuhan akan nutrisi juga meningkat.

Untuk menentukan ukuran kemiskinan absolut kadang-kadang ukuran tingkat kebutuhan biologis tidak terlalu tepat. Dalam beberapa kasus kemiskinan, ukuran kebutuhan biologis tidak mencerminkan suatu kemiskinan absolut. Jadi konsep garis kemiskinan hanya dapat berjalan ketika kita berada dalam ruang lingkup sosial. Bila dalam ruang lingkup sosial tertentu menerapkan suatu standar hidup yang lebih tinggi maka individu berusaha menyesuaikan standar sosial berdasarkan standar lingkungannya. Konsep garis kemiskinan ini menjadi bahan perdebatan diantara beberapa negara. Hal ini disebabkan karena konsep ini mencerminkan perbedaan taraf ekonomi, sosial dan pembangunan ekonomi. Dengan kata lain, ukuran kemiskinan ini akan berubah menurut waktu.

Dalam beberapa penelitian, ukuran yang paling banyak dipakai dalam pengukuran garis kemiskinan adalah total belanja konsumsi yaitu total konsumsi yang memenuhi 
kebutuhan dasar sebesar 2.250 kalori tiap hari per individu. Walaupun jumlah orang yang berada di bawah garis kemiskinan dalam standar tersebut selalu berubah dari tahun ke tahun, tetapi dipastikan kira-kira $40-50 \%$ dari total populasi dunia berada di bawah garis kemiskinan.

Tetapi

berdasarkan

pendekatan income based, untuk menentukan kemiskinan, teori ini tidak secara eksplisit menghitung kebutuhan individu di dalam pemenuhan tingkat minimum jasajasa publik seperti kesehatan, pendidikan, kebutuhan akan air bersih, dan sanitasi. Hal-hal tersebut merupakan bagian yang penting di dalam konsep kemiskinan secara utuh dan merupakan hal yang sangat penting di dalam rancangan program pengurangan kemiskinan.

\section{Pengangguran}

Menurut Raper dalam Brotherhood (2002) pengangguran adalah penyebab kemiskinan terbesar dan perlu diberantas, tetapi hanya dapat diatasi salah satunya dengan cara menyediakan pekerjaan dan kesempatan kerja, daripada hanya sekedar himbauan atau slogan-slogan saja.

Pengangguran bukan semata-mata hanya masalah bagi mereka yang tidak memiliki pekerjaan, melainkan masalah bagi kita semua. Jika masyarakat tidak memiliki dana untuk dibelanjakan, maka perusahaan tidak dapat menjual produknya, dan dampaknya akan mempengaruhi seluruh perekonomian. Langkah pertama untuk mengurangi pengangguran adalah dengan mengakui bahwa pengangguran bukanlah akibat seseorang yang malas, melainkan masalah struktural.

Menurut Brotherhood (2002)

Hal ini berarti pemerintah mempunyai peran dalam menerapkan kebijakan yang sesuai. Jika pemerintah melakukan investasi dalam penyediaan lapangan kerja, hal ini tidak hanya akan menjaga stabilitas perekonomiannya, tetapi juga akan menciptakan banyak kesempatan bekerja.

Menurut Arief dalam Gemmel (1992), Indonesia merupakan suatu kasus di mana pertumbuhan bertumpu pada industri padat modal dan pengeboran minyak bumi, ditambah dengan pengembangan pertanian yang cenderung hemat tenaga kerja. Jenis pengembangan demikian berarti bahwa permintaan akan tenaga kerja tidak terampil tetap rendah sehingga tingkat pengangguran bertambah, dan hal ini berarti bahwa tingkat kemiskinan hampir pasti naik.

\section{ANALISIS}

Analisis deskriptif-kualitatif
disusun berdasarkan metode
penelitian dengan pengujian
terhadap data sekunder yang
diperoleh dari berbagai sumber
data, jurnal, artikel, buku, majalah,
internet dan studi literatur ilmiah
yang berkaitan dengan
permasalahan yang sedang diteliti.
Sesuai dengan alasan utama
mengapa banyak Negara


berkembang yang tetap mengalami peningkatan kemiskinan, yaitu Pertama, banyak negara berkembang yang telah mengalami laju pertumbuhan GDP yang pesat, secara berbarengan juga mengalami pengangguran yang meningkat. Laju pertumbuhan lapangan kerja ternyata jauh lebih lamban dari laju pertumbuhan GDP.

Bila seseorang berada dalam keadaan menganggur berarti ia tidak mendapatkan tambahan penghasilan dalam memenuhi kebutuhan hidupnya. Terlihat bahwa apabila seseorang itu menganggur maka akan membuat ia terlihat miskin karena tidak bisa memenuhi kebutuhan pokok dalam sehari-hari. Dalam kaitan itulah maka patut diduga pengangguran mempunyai dampak terhadap kemiskinan.

Berdasarkan penelitian penelitian sebelumnya oleh Arief dalam Gemmel (1992), dimana Indonesia bertumpu pada industri padat modal dan pengeboran minyak bumi, ditambah dengan pengembangan pertanian yang cenderung hemat tenaga kerja yang berarti bahwa permintaan akan tenaga kerja tidak terampil tetap rendah sehingga tingkat pengangguran bertambah, dan hal ini berarti bahwa tingkat kemiskinan hampir pasti naik.

Begitu pula penelitian yang dilakukan oleh Brotherhood (2002) yang menyimpulkan bahwa pemerintah mempunyai peran dalam menerapkan kebijakan yang sesuai. Jika pemerintah melakukan investasi dalam penyediaan lapangan kerja, hal ini tidak hanya akan menjaga stabilitas perekonomiannya, tetapi juga akan menciptakan banyak kesempatan bekerja. Untuk memperoleh pekerjaan, setiap individu memerlukan skill yang dibutuhkan pekerjaan tersebut, maka akses terhadap pelatihan sangat penting.

Maka perlu diciptakan kebijakan oleh pemerintah daerah yang dapat meningkatkan permintaan akan tenaga kerja tidak terampil agar memudahkan penduduk miskin menjual tenaga kerja mereka dan mengurangi jumlah penganggur atau dengan memberikan akses pelatihan yang berguna untuk tenaga kerja tidak terampil tersebut. Dengan cara ini, kekuatan pasar akan mendukung kebijakan pengentasan kemiskinan.

Beberapa kebijakan yang direncanakan Ahok sebagai Kepala Daerah dalam rangka membuka kesempatan kerja diantaranya merekrut ribuan Pegawai Harian Lepas (PHL) serbaguna yang bertugas untuk menjaga dan memantau kebersihan dan jalanan rusak di setiap kelurahan. Hal itu dapat mengurangi jumlah pengangguran yang ada di DKI Jakarta.

patut Kebijakan lain yang juga Okezone.com adalah Ahok melarang pengangguran datang ke DKI Jakarta pasca lebaran. Ahok mengantisipasi lonjakan urbanisasi yang selalu terjadi setiap tahunnya, yaitu dengan melakukan pemindahan berbagai pabrik industri dari semula berada di Jakarta dipindahkan ke daerah lain yang 
juga berada di pulau Jawa. Walaupun kebijakan ini berbeda pemikiran dengan Arief yang mengatakan bahwa Indonesia masih bertumpu pada industri padat modal yang menghemat tenaga kerja, diharapkan kebijakan yang diambil betul-betul dapat terealisasi mengalihkan urbanisasi setiap tahunnya.

Kebijakan lainnya oleh Ahok
sesuai dengan penelitian
Brotherhood yaitu perlunya akses terhadap pelatihan, maka kebijakan untuk membebaskan persyaratan pendidikan formal bagi warga agar bisa mengikuti pelatihan di Balai Latihan Kerja (BLK) juga patut didukung oleh pihak-pihak terkait yaitu Kementerian Ketenagakerjaan. Kebijakan ini juga diharapkan dapat meningkatkan kualitas sumber daya manusia dalam menjelang Masyarakat Ekonomi ASEAN (MEA) tahun 2015. Peningkatan kualitas sumber daya manusia ini penting dilakukan karena warga negara Indonesia nantinya akan bersaing dengan warga dari negara lainnya.

\section{KESIMPULAN}

Berdasarkan pada teori-teori dan analisis mengenai dampak pengangguran terhadap kemiskinan di DKI Jakarta, maka dapat disimpulkan bahwa pengangguran yang terjadi di DKI Jakarta mempunyai kecenderungan untuk meningkat setiap tahunnya.

Peningkatan pengangguran di negara-negara yang sedang berkembang disebabkan oleh lambatnya kesempatan kerja daripada pertumbuhan yang cepat dari angkatan kerja.

Pengangguran mempunyai dampak terhadap kemiskinan, walaupun berdasarkan data dari BPS jumlah pengangguran mengalami penurunan tiap tahunnya. Perlu diciptakan kebijakan oleh pemerintah daerah yang dapat meningkatkan permintaan akan tenaga kerja tidak terampil agar memudahkan penduduk miskin menjual tenaga kerja mereka dan mengurangi jumlah penganggur atau dengan memberikan akses pelatihan yang berguna untuk tenaga kerja tidak terampil tersebut. Dengan cara ini, pemerintah banyak memberikan bantuan guna menunjang pertumbuhan ekonomi dan mendorong berkembangnya kegiatan ekonomi masyarakat.

Ada beberapa kebijakan yang direncanakan Ahok sebagai Kepala Daerah dalam rangka membuka kesempatan kerja diantaranya merekrut ribuan Pegawai Harian Lepas (PHL), Ahok melarang pengangguran datang ke DKI Jakarta pasca lebaran, jadi sudah berfokus pada warga pengangguran yang sudah ada di kota ini dengan melakukan pemindahan berbagai pabrik industri dari semula berada di Jakarta dipindahkan ke daerah lain yang juga berada di pulau Jawa, serta kebijakan untuk membebaskan persyaratan pendidikan formal bagi warga agar bisa mengikuti pelatihan di Balai Latihan Kerja (BLK) dalam rangka dapat meningkatkan kualitas 
sumber daya manusia dalam menjelang Masyarakat Ekonomi ASEAN (MEA) tahun 2015.

\section{DAFTAR PUSTAKA}

Badan Pusat Statistik, 2000. Laporan Perekonomian Indonesia 2000, Jakarta.

Brotherhood of St. Laurence, 2002. Unemployment and Poverty, Australia.
Doshi, Kokila P. 2000. Inequality and Economic Growth, University of San Diego.

Gemmell, Norman, 1992. IImu Ekonomi Pembangunan Beberapa Survey. Jakarta : Penerbit PT Pustaka.

World Development Report, 1990.

Poverty, Washington DC:

Oxford University Press.

www.bps.go.id

www.kompas.com

www.okezone.com 